Алешина Эржена Стальевна канд. пед. наук, старший преподаватель ГАУ ДПО РБ «Бурятский республиканский институт образовательной политики» г. Улан-Удэ, Республика Бурятия Хепнер Татьяна Николаевна директор

МАУ ДО «ДШИ №6» г. Улан-Удэ г. Улан-Удэ, Республика Бурятия

DOI $10.21661 / r-473920$

\title{
СОЦИАЛИЗАЦИЯ ДЕТЕЙ С ОГРАНИЧЕННЫМИ ВОЗМОЖНОСТЯМИ ЗДОРОВЬЯ В УСЛОВИЯХ ДЕТСКОЙ ШКОЛЫ ИСКУССТВ
}

Аннотация: в статье раскрываются особенности соичализации детей с ограниченными возможностями здоровья (ОВЗ) в условиях детской школьи искусств. Авторами сделан акиент на роли искусства в психологическом оздоровлении обучающихся, формировании у них навыков успешной коммуникации. В работе описываются структура образовательной и воспитательной деятельности школь, основные направления, технологии и формы обучения детей с ОВЗ, обобщаются проблемы, результаты, достижения инклюзивного художественного образования.

Ключевые слова: сочиильная адаптаџ̧ия, соџиализаџчия детей с ограниченными возможностями здоровья, интеграция в современное общество, детская школа искусств, художественное образование, творческое развитие, одаренHole demu.

Создание условий для успешной социальной адаптации и интеграции ребенка в современное общество является сегодня одной из приоритетных задач в России. Одной из важных задач деятельности ДШИ является успешная социализация и творческое развитие художественно одаренных детей. Среди детей, проявляющих способности к искусству, есть и дети с ограниченными 
возможностями здоровья (OB3). Несмотря на то, что ДШИ традиционно обучаются здоровые дети из благополучных семей, в последние годы количество детей с ОВ3 в школах искусств увеличилось.

Поэтому актуальность данной проблемы обусловлена, с одной стороны, ростом числа детей, имеющих ограниченные возможности здоровья, а с другой неготовность большинства преподавателей ДШИ качественно осуществлять процесс социальной поддержки и обучения детей с ОВ3.

Эти дети требуют к себе повышенного внимания и заботы, особого подхода, учета индивидуальных возможностей ребенка. Очень важно для детей с ОВ3 создать творческую развивающую среду. Работа преподавателей ДШИ направлена на гармоничное развитие детей средствами искусства.

Искусство способно вызывать у детей с ОВ3 яркие эмоции, оно способствует повышению их самооценки, психологическому оздоровлению, развитию их мышления, положительно влияет на состояние их здоровья, формирует навыки коммуникации с другими членами общества.

Специфика школы искусств позволяет интегрировать детей в творческий исполнительский процесс. Поэтому особое значение в социальной адаптации детей с ОВ3 придается творческой деятельности посредством их активного включения в творческую исполнительскую деятельность. Участие ребёнка с ограниченными возможностями в концертах, выставках, праздниках вместе со здоровыми детьми помогает им почувствовать полноценными членами общества, развить и реализовать свои таланты.

Основной функцией образовательного процесса для детей с ОВЗ в ДШИ является снятие нервно-психического напряжения, моделирование положительного психоэмоционального состояния, формирование адекватного межличностного поведения, самооценки. Для развития и социализации детей с OBЗ в ДШИ используются различные технологии и формы обучения. Структура образовательной и воспитательной деятельности включает разнообразные направления, позволяющие добиться положительных результатов в творческом развитии детей с особенностями развития. 
Социальная адаптация детей с ОВ3 в ДШИ проводится как в форме индивидуальных занятиях, так и в смешанных группах обучения. Практика работы свидетельствует, что они быстрее приспосабливаются к окружающим условиям, учатся действовать и жить в творческом коллективе, учатся эффективному общению со сверстниками и взрослыми.

Важно отметить и большую роль родителей детей с ограниченными возможностями здоровья, которые принимают активное участие в проведении культурно-досуговых мероприятий школы. Несмотря на все положительные моменты, которые связаны с занятиями в ДШИ, не все школы располагают в достаточной мере условиями и современными средствами обучения детей с ОВ3. Поэтому школам искусств необходима финансовая, методическая поддержка для работы с данной категорией детей.

Анализ результатов работы с детьми с ОВ3 позволяет сделать вывод о правильности выбранного направления школой искусств и целесообразности используемых методов и форм работы. Об этом свидетельствуют:

1. Устойчивая заинтересованность детей с ОВ3 и их родителей в обучении в школе искусств.

2. Положительная динамика наблюдается у детей с ОВ3 в развитии познавательных процессов и навыков социализации. У обучающихся с нарушением речи и слуха, координации движений наметилась тенденция к улучшению речи, развития мышления, объема памяти. В процессе общения с детьми наблюдается значительный рост их самооценки, развитие их коммуникативных навыков.

3. Дети получили возможность быть вовлеченными в коллективную творческую деятельность. Они с желанием посещают концерты, выставки, участвуют в подготовке к культурным мероприятиям школы, праздникам.

4. Достижения многих детей отмечены грамотами участия и дипломами победителей в фестивалях и конкурсах.

5. Преподаватели школы терпеливо и внимательно обучают детей искусств. В учреждении создана благоприятная атмосфера открытости, доверительного отношения друг к другу. 
Посещая детскую школу искусств, дети с ОВ3 получают возможность расширить круг общения со сверстниками, включиться в творческую работу, обнаружить и развить свои способности, научиться взаимопомощи, приобрести опыт творческой деятельности и успешной социализации. 